\section{SOI: $1.1 / \mathrm{TAS} \quad$ DOI: $10.15863 / \mathrm{TAS}$ \\ International Scientific Journal Theoretical \& Applied Science}

Salamat Perdebaevich Saparov

Teacher,

Department of the English language and literature,

Nukus State Pedagogical Institute

named after Ajiniyaz, Uzbekistan ssp-81@mail.ru

Year: 2015 Issue: 05 Volume: 25

Published: $30.05 .2015 \quad$ http://T-Science.org

SECTION 29. Literature. Folklore. Translation Studies.

\title{
LINGOCULTUROLOGY AND PHRASEOLOGICAL UNITS AS LINGOCULTUREME
}

\author{
Abstract: In given article we mentioned a question about lingoculturology and phraseological units as \\ lingocultureme, as well as about attitudes in area adjectival comparative phraseological units. \\ Key words: National speech, lingoculturology, phraseological units, lingocultureme, adjectival, native \\ speakers, national colloquial language, substantive. \\ Language: Russian \\ Citation: Saparov SP (2015) LINGOCULTUROLOGY AND PHRASEOLOGICAL UNITS AS \\ LINGOCULTUREME. ISJ Theoretical \& Applied Science 05 (25): 173-176. \\ Soi: http://s-o-i.org/1.1/TAS*05(25)33 Doi: crossef http://dx.doi.org/10.15863/TAS.2015.05.25.33

\section{ЛИНГВОКУЛЬТУРОЛОГИЯ И ФРАЗЕОЛОГИЧЕСКИЕ ЕДИНИЦЫ КАК ЛИНГВОКУЛЬТУРЕМЫ}

Аннотация: В данной статье нами затронут вопрос о лингвокультурологии и фразеологических единииах как лингвокультуремах, а также об отношениях в сфере адъективных компаративных фразеологических единиц.

Ключевые слова: Всенародная речь, лингвокультурология, фразеологические единицы, лингвокультуремы, адъективные, носители языка, народное просторечье, субстантивность.

Фразеология в любом языке является достоянием всенародной речи, авторы которых стали не известными в продолжительности далёких времен из-за отсутствия письменности в древности. Они, как золотой фонд речевой деятельности того или иного народа, передавались от поколения к поколению от уста в уст носителями определенных языков. Поэтому большинство этих речевых явлении являются исконно народными оборотами, отражающими их самобытность, обычаи, традиции, родственные отношения, родные земли, поверья, предметы культуры и материального быта, реалии, предания и исторические факты.

Каждый народ за своё появление в свет и существование первым долгом признателен Матери-природе, Всевышнему создателю вселенной и земли, самой жизни - Богу. Поэтому каждый народ начинает свою речь с Божьего слова - The word of God -Кудайдың хуәмри, Алланың худми. Например: The Seed is the word of God, Зернышко есть - Божсье слово, Бир түйир дәнде - Алланың хрәри. Либо каждое существо есть результат Божьего слова - как сама жизнь началась с Божьего слова. [2, с. 1037. 1269.].

Словосочетание Ақ пәтия (Богословье), Алдыңды алла ашсын - (пуст Бог сопутствует тебе) в народном речении употребляется как добрые пожелания от имени самого Бога, а также в любом народе каждый себя считает Божьим рабом - The servant of the God - Кудайдың бендеси.

В народе издавна существует речения фразеологизмы, которые описывают характерные черты, лучшие образы женщин, которые связаны с именем матери матерей Бийпатпь покровительницы всех женщин в исламском мире: Hazblз Бийпатпаның өзи - досл. Just as Biypatpa, Hazblз Бийnатпаның тухымы - Born of Eve (daughters of Eve - женщины, женский пол; дочери Евы; Ева - первая женщина, супруга Адама). Так говорят когда говорящий или создатель литературных образов хочет выражать свою поражённость и восхищение относительно красоте, нежности, обаятельности и другим положительным качествам представительницы 
прекрасного пола. В книге С.Т. Наурызбаевой «Фразеологические единицы в каракалпакскорусском словаре» приведен ФЕ включающая имени покровительницы всех женщин в исламском мире «Хәзирети бийпатма» покравительница женщин [8, с. 82]. Однако здесь имя написано прописной буквой и ФЕ представлено как субстантивная ФЕ, хотя чаще и чаще в народном просторечии мы услышим ее в адъективной форме. В адъективной форме она встречается в виде оборотов «навыз Пийрим Бийпатманың тухымы екен», «навыз Пийрим Бийпатмадай» адам еди... последняя фраза обычно произносится в похоронах. В английском языке фразеологизмы такого рода в словаре А.В. Кунина 1984 «The daughter of Eve» которая наш взгляд может являться аналогом выше приведенной ФЕ «Бийпатпаның тухымыз». В процессе речи говорящий опирается на свой социальный опыт и сополагает слова, которые могут сочетаться в данном обществе, то есть социальное структуры являются материальной под основой лингвистических структур. Социальные дифференциации проявляются особенно ярко и не посредственно в словарном составе каждого языка, в том числе, и в фразеологизмах, где наряду с особенностями присущих отдельным языкам могут встречаться и межъязыковые соответствия относящихся к разным системам английского и каракалпакского языков. Например: слово aқ - white обозначающий цвет имеют положительную окраску в обоих сопоставляемых языках. Белый цвет это - цвет чистоты души человеческой и он отражает в фразеологизмах добрые качества: White house - Ak yй, Aқ̧ omay̆; the white man - ak кеўил; white race - хуақ жол. Фразеологизмы с компонентом $а қ$ в каракалпакском языке гораздо чаще чем в английском. Например: Ақ̧ көкирек, ақ кеўил, ақ пейил, ақ сүйек, ақ қуба, ақ сабан, ақ отаў. Ақ көкиректиң аты азбайды тоны тозбайды. (каракалпакская народная пословица) досл. Good-natured man's name is never forgotten and his coat is never worn. Ақ дегени алzыс құара дегени варвыс больп турван адам. (Джумамуратов. РКФС. 1985. С. 28). Однако, по данным примерам ФЕ в «Англо-русском фразеологическом словаре» А.В. Кунина наше доверие на белый цвет не оправдывается полностью первая же АФЕ с компонентом "white" lily-white употребляется как бы относительно расовой дискриминации: 545. I. Lily-white - состоящий только из белых, не имеющий в своем составе ни одного негра; только для белых. Пример: "Particularly contemptible was the Jim Crow attitude of the southern white churches, which evidently looked forward to a Lily-white heaven" (W. Foster History of the Communist party of the United States, ch.8).
Әсиресе негрлерге елдиң кубласындагы ширкеўлерде жаман қатнаста болатын еди. Олар өзинше исенимли түрде аспан патшашылызы тек ақлар ушын ашық деген пикирге исенетугын еди. А АФЕ с порядковым номером 546 - as white as a sheet (as ashes или as death) - (рус. Бледный, как полотно, смертельно бледный). сүптей ақ (мархумzа жабылатын тауар, материал), тоже употреблено не по доброй воле. Нижеследуюший пример подтверждает этот факт, «... the poor thing turned white as a sheet, and would have fallen if I had caught hold of her» (H. Haggart. Stella Fragelius. Ch. XVIII) «... бийшара қыblз суптей аварып кетти егер мен оны услап құалмаванымда жерге жыгылып түскен болар еди. Еще неприятные звучит примеры с дальнейшими номерами 549. white slave - белая рабыня (девушка, вынужденная заниматься проституцией) - түнги гөбелек. 550. White slaver - поставщчик жсивого товара.(см. тж. 549) 551. White slavery - нәпси бәлесине жольққанлар (проституиция см. тж. 549). 552. White-slave traffic - адам саўдасы менен шувылланыу (хаял қызлар) (торговля живым товаром см. тж.549). Производные ФЕ от white slave более очерняет белый цвет. [7, c. 1019-1020].

Среди широкого спектра социокультурных реалии отражающих менталитет историю и культуру каждого народа наибольшую социокультурную ценность по словам Е.М. Верешагена и В.Г. Костомарова «нужно искать преимущественно у слов, фразеологизмов и афоризмов». (Язык и культура. М. 1990г. С. 182). Пословицы, поговорки и фразеологизмы являются строевыми элементами языка в них содержатся информация, которые отражает, хранит и передает из поколения в поколение обычай и культуру, историю и искусство народа, характеризует быт и нравы, психологические особенности и темперамент. Все анализируемые фразеологизмы разделяются на 3 группы: [9]

1. Эквивалентные совпадающие по содержательной и образной структуре у разных языков, рассмотрим английские ФЕ имеющие полные эквиваленты в каракалпакском языке: Cheap and musty - арзанның сорпасы татымас; walls have ears - тамның (дийуалдың) да қулавы бар; strike the iron while it is hot - темирди қыззанда бас (сок); love can not be forced сүймегенге сүйкенбе; better late than never хештен кеш жақсы; the furthest way about is the nearest way home - айланыш болсада жол жақ̆сbl; all is not gold that glitters жалтыраванның бәри алтын емес; as scared as a rabbit - қояндай қорқұақ; needles to say айтпасада түсиникли.

2. Частично эквивалентные совпадающие по содержанию, но имеющие разные образцы. 
Таким ФЕ относится: one's bitten twice shy - aўзы күйген үрлеп ишеди; Guests at scars that never felt a wound - басы аўырмаганның қудай менен иси жоқ; neither hey nor grass - я ары я бери емес. (ни рыба ни мясо). Из приведенных примеров видно, что источником создания образности у разных народов являются разные объекты, это объясняется тем, что свои лучшие помысли, надежды, мечты они связывали каждый по своему. Каракалпаки, например, издревле связывали со скотом, среди которых особое место отводится верблюду: Түйениң Үлкени көпирде таяқ жейди -(рус.старший всегда виновен) смысловое значение The eldest is always guilty, досл. The eldest camel is bitten on the narrow bridge; жантақ керек болван түйе мойнын cозады - (рус.без труда не вымнешь рыбу из пруда) - need makes the old wife trot (нужда многому научит); Ақ түйени көрмедим деген қутылады - (рус.кто осторожен тот спасается) - save one's bacon (спасать себя, свою (или чью-л.) шкуру) Clarke aroused loathing and contempt because he had turned informer to save his skin... (K. S. Prichard, 'Golden Miles', ch. 57) - Кларк вызывал презрение, гадливость, потому что стал доносчиком ради спасения своей шкуры... досл. Who does not see the white camel is not guilty.

3. Безэквивалентные ФЕ представляют наибольший интерес для межкультурный коммуникаций. Английские ФЕ типа Right to privacy - (права на собственность) жеке мениик хуқ̧ық. Пословица My house is my castle - өз үйим өлем төсегим. Эти устаявшие выражение подтверждают что у англичан (Американцев) понятия personal space, privacy of the individual (личная зона) өз ийелиги, особо соблюдается. И в воспитании у англичан особо важный традиции уважения к личности человека, не принято переходит личностные границы, то есть, не допускать фамильярности. Семья, дом, для них это крепость, куда посторонним вход запрещен. Среднеазиатские народы, в том числе каракалпаки отличаются гостеприимством, дом у них всегда открыт для званных и не званых гостей, своих и чужих, поэтому у каракалпакского народа существует понятие (фразеологизм) Кудай құонақ (гост посланным Богом) - The guest sent by God, которому вопреки любым обстоятельствам оказывается большое гостеприимство. Этими своеобразными характеризующими чертами насыщены пословицы и поговорки, Жаўда да бир үйин болсын дейтувын, тапса биреўин таппаса екеўин соятын, (мәрт халық, добрый народ). «Это означает, что каракалпаки в любой момент вопреки любым обстоятельством готовы оказывать гостеприимство гостю. В одном анекдоте говорится, что хан и его нукеры заблудившись во время охоты, остановятся у шалаша пастушонка. Голодные они просят пастушонка чего то съедобного тут пастушонок просит их войти в свой шалаш и разводит достархан и режет свою единственную козу которая уже близко к роду один из нукеров удивленно спросит пастушонка а почему ты рез эту козу ведь она беременна и ждет козленка тогда мальчик отвечает каракалпак такой народ найдет - режет одну, не найдет - режет двух"». (каракалпакские народные сказки). И каракалпаки соблюдают традиции уважения к личности человека. Об этом свидетельствует эти строки из стихотворения великого каракалпакского поэта Ажиняза.

«Өтирикти рас етип айтпаван,

Бас кетседе туўры жолдан кайтпаван

Нәмдхремди хасла жолдас тутпаван

Аты қарақалпақ еллерим барды

Рух..............................

Аты қарақалпақ еллерим барды. (Ажинияз. «Еллерим барды»).

В этом стихотворении АФЕ өтирикти рас етип айтпаван, туйры жолдан бас кетседе кайтпаван, ндмдхремди хасла жолдас тутпаван, бир-бирине салмас из характеризует традиции уважения к личности каракалпакского народа.

Число безэквивалентных АФЕ каракалпакского языка пополняются оборотами как 1) Жантақлы жердиң сонасындай (адамға жақпайтуғын, как с осиного гнезда); 2) Сегиз кырльы сазанды товыз кырльр жигит aлadbl.(крепкого сазана ловит только ловкий рыбак); 3) пәрўайы пәнсери (безразличный); 4) өз байдалына кеткен (не воспитанный). Выше приведенные примеры ФЕ каракалпакского языка на английский язык могут передаваться путем калькирования или дословного перевода. 1) as gadflies from sticky bushes 2) a big sazan is caught by a skillful fisher 3) indifferent 4) unobeyed.

В английском языке по отношению с каракалпакским языком более безэквивалентными является АФЕ enough to make a cat speak - хайран қаларльқ (досл. пышыққа да зибан ендирерлик); grin like a Cheshire cat - биймәни күлип жүретин адам [английское выражение приобрело особую популярность благодаря книге Л. Кэрролла "Алиса в стране чудес"] 'Please, would you tell me,' said Alice a little timidly... 'why your cat grins like that?' 'It's a Cheshire cat,' said the Duchess, 'and that's why.' (L. Carroll, 'Alice's Adventures in Wonderland', ch. VI) [словарь ABBYY Lingvo 12]. - - Пожалуйста, скажите мне, - спросила Алиса, робко... - почему ваша кошка так ухмыляется? Потому что это чеширская кошка, - сказала герцогиня, - вот почему. Айтыңызшы деди Алиса сәл уялыңқырап не ушын сизиң пышывыңызз бәрхулла биймәни ыржыйып жүреди? - себеби 
ол Чешир пышызы да деп жуўап берди гериогиня әне сол (себеби). The riddle of the sphinx (sphinx's riddle) - Сфинкс жумбавы (загадка сфинкса, очень трудная загадка). Как в большинстве случаев подтверждают словари особенно большой Оксфордский словарь происхождение даже самых странных идиомов имеет свои корни в определенных народных обычаях связано с их образом жизни и культурой. Например: При разыскании истории происхождения To spoil a ship for a ha'p'orth ( устаревшее сокращение от half-penny-worth - чтол. ценой в полпенни). Испортить, потерять, что либо ценное из за мелочной экономии, (в каракалпакском языке қ̧ас қ̧ояман деn көз шызарыў), писалось раньше to spoil a sheep и значило потерять (от болезни) овцу пожалев несколько грошей на деготь (для излечения). Выражение as plain as a pikestaff - аттай анық (ясно как день). Не имеет никакого отношения к шуке как могло бы показаться первоначально говорили as plain as pikestaff, то есть такая же простая речь как дощечка - подпорка носильщика, коробейника. The pikestaff плоская дощечка которая употреблялась в кухне для обработки не только щуки, а всякой рыбы (даже мясо и овощей), значить первоначально она употреблялась в кухне рыбацкой семьи и они просто называли его pikestaff. [10, с. 33].
В любом языке человеческая речь не может адекватно передать все неистощимое богатство жизни с её взаимосвязями все мысли и чувство; литературный язык, словообразовательные возможности которого ограничены, всегда готов заимствовать имеющиеся уже в обиходе специальный термин, которому можно придать более широкое значение. Идиомы, удачные поговорки созданные людьми, занятыми в различных сферах деятельности и спорта, будучи краткими разговорными, отражающими бьющим ключом жизнь всегда находит применение в выразительной речи. Значит, все виды человеческой деятельности имеют свою лексику, свои специальные термины, проникающие иногда особенно в метафорическом употреблении в литературный язык. Моряки в плавании, охотники на охоте, крестьяне на полях, повара на кухне все кому срочно требовалось выразиться; отдать приказ, выразить благодарность, признательность, предупреждение, угрозу, упрёк - умели находить яркие сочетание слов, красочные метафоры, связанные с обстоятельствами своей деятельности.

Таким образом, при этимологии той или иной фразеологической единицы, «необходимы не только лингвистические исследования, но и глубокие знании истории, быта и культуры народа, который являются творцом национального языка» [8, с. 69].

\section{References:}

1. (1933) OED - The Oxford English Dictionary. 13 vol. Oxford: Clarendon Press, 1933.

2. (1997) The Compass: Holy bible - New Life Version with Topical Study Outlines Paperback - 1997 by Christian Literature International .

3. Berdimuratov E (1994) Hazirgi karakalpak tili leksikologiyasy. - Nokis: Bilim, 1994.

4. Eshbaev Z (1985) Karakalpak tilinin kyskasha frazeologiyalyk sozligi. Nokis: Karakalpakstan, Baspasy, 1985

5. Kamenetskayte NL (1971) Sinonimy v angliyskoy frazeologii. Moscow, 1971. -367 p.
6. Kud'yarova ST (2008) Karakalpak ham kazak tillerindegi sozlerdin lekska-semantikalyk ozgeshelikleri. Nokis: Karakalpakstan, 2008.

7. Kunin AV (1967) Anglo-russkiy frazeologicheskiy slovar'. Okolo 25000 frazeologicheskikh edinits. - Moscow, 1967.

8. Nauryzbaeva ST (1972) Frazeologicheskie edinitsy v karakalpaksko-russkom slovare. Tashkent: Fan, 1972.

9. Rzaeva R (2007) Lingvo-sotsiokul'turnye aspekty prepodavaniya angliyskogo yazyka. «Nauka i obshchestvo» № 1-2. - Nukus, 2007.

10. Smit L (1959) Frazeologiya angliyskogo yazyka. - Moscow, 1959. 